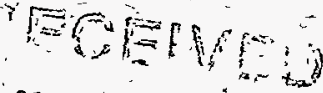 \\ MAR 11 ISBS \\ OSTI
}

\section{Cost Effectiveness of the 1995 Model Energy Code in Massachusetts}

R. G. Lucas

February 1996

Prepared for

the U.S. Department of Energy

Contract DE-AC06-76RLO 1830

Pacific Northwest National Laboratory

Operated for the U.S. Department of Energy

by Battelle

\%B Battelle 


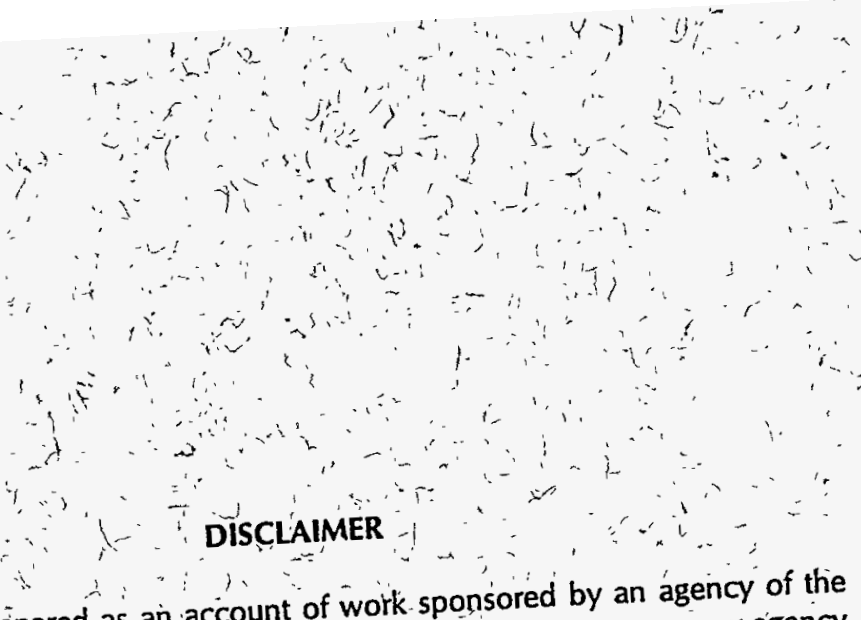

This report was prepared as an account of work sponsored by an agency of hor United States Government. Neither the nur any of their employees, makes any thereof, nor Battelle Memorial Institute, ho any of hell lity or responsibility for warranty, express or implied, or assumes any lo information, apparatus, product, the accuracy, completeness, or usefulnes wo would not infringe privately owned or process disclosed, or represents that its use would process, or service by - rights, Reference herein to any specific com otherwise does not necessarily constitute trade name, trademark, manufacturer, on othen or favoring by the United States cr imply its endorsement, recommendation, or Government or any agency thereof, or Battelle necessarily state or reflect those of the opinions of authors expressed herein doncy thereof.

$$
\begin{aligned}
& \text { PACIFIC NORTHWEST NATIONAL CABORATORY } \\
& \text { BATTELLE MEMORIAL INSTITUTE } \\
& \text { A for the } \\
& \text { UNITED STATES DEPARTMENT OF ENERGY } \\
& \text { under Contract ḊE-AC06-76RLO } 1830
\end{aligned}
$$

Printed in the United States of America

Available to DOE and DOE contractors, from the

, Box 62, Oak Ridge, TN 37831;

Office of Scientific and Technical thlable from (615) 576-8401:

prices available from (615) 576-8401:

Available to the public from the National Technid.

U.S. Department of Commerce, 5285 Port Royal Rd., Spring

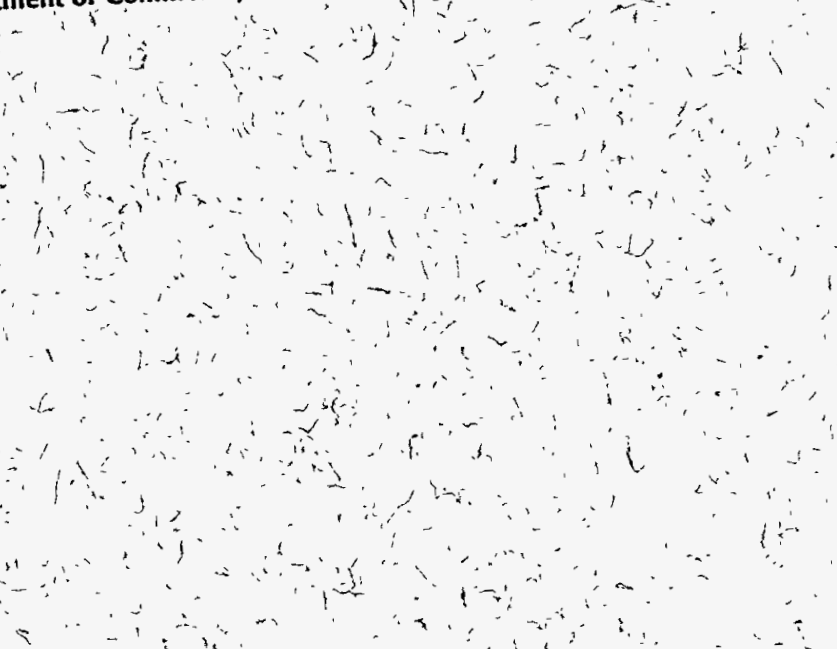

The contents of this report are printed on recycled paper. 
PNNL-10975

UC-350

\section{Cost Effectiveness of the 1995 Model Energy Code in Massachusetts}

R. G. Lucas .

February 1996

Prepared for the U.S. Department of Energy under Contract DE-AC06-76RLO 1830

Pacific Northwest Laboratory Richland, Washington 99352

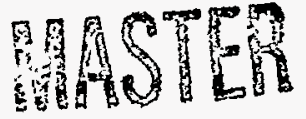

DISTRIEUTION OF THIS DOCLSUEMT IS UALMTED 


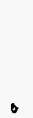

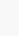




\section{Summary.}

This report documents an analysis of the cost effectiveness of the Council of American Building Officials' 1995 Model Energy Code (MEC) building thermal-envelope requirements for single-family houses and multifamily housing units in Massachusetts. The goal was to compare the cost effectiveness of the $1995 \mathrm{MEC}$ to the energy conservation requirements of the Massachusetts State Building Code--based on a comparison of the costs and benefits associated with complying with each. . This comparison was performed for three cities representing three geographical regions of Massachusetts-Boston, Worcester, and Pittsfield.

The analysis was done for two different scenarios: a "move-up" home buyer purchasing a single-family house and a "first-time" financially limited home buyer purchasing a multifamily condominium unit.

Natural gas, oil, and electric resistance heating were examined. The Massachusetts state code has much more stringent requirements if electric resistance heating is used rather than other heating fuels and/or equipment types. The MEC requirements do not vary by fuel type. For single-family homes, the $1995 \mathrm{MEC}$ has requirements that are more energy-efficient than the non-electric resistance requirements of the current state code. For multifamily housing, the $1995 \mathrm{MEC}$ has requirements that are approximately equally energy-efficient to the non-electric resistance requirements of the current state code. The $1995 \mathrm{MEC}$ is generally not more stringent than the electric resistance requirements of the state code, in fact; for multifamily buildings the 1995 MEC is much less stringent.

For the single-family home buyer of a home heated with natural gas or oil, compliance with the 1995 MEC was estimated to increase first costs by between $\$ 1273$ and $\$ 1738$, resulting in an incremental down payment increase of $\$ 255$ to $\$ 348$ (at $20 \%$ down). The time when the homeowner realizes net cash savings accounting for all costs and savings for houses built in accordance with the 1995 MEC was from 2 to 3 years. That is, the home buyer who paid $20 \%$ down had recovered increases in down payments and mortgage payments in energy cost savings by the end of the 3 years or sooner and thereafter will save more money each year.

For the buyer of a unit in a multifamily building heated with natural gas or oil, compliance with the 1995 MEC would only raise construction costs in colder parts of the state. First costs were estimated to vary from a decrease of $\$ 343$ in Boston to an increase of $\$ 125$ in Pittsfield. The time when the homeowner realizes net cash savings for multifamily buildings built in accordance with the $1995 \mathrm{MEC}$ was 2 years or less.

For electric resistance heating and the single-family home, the Massachusetts code requirements and the 1995 MEC requirements are for all practical purposes, equally stringent. For multifamily buildings with 
resistance heating, the Massachusetts code is much more stringent than the MEC.

It is likely that most new housing in Massachusetts exceeds some of the requirements of the current state code. Most notably, the current state code normally allows any type of double-paned window. A recent survey found most new houses in Massachusetts have much more energy-efficient windows than the double-paned aluminum windows (U-0.72) assumed in this report for state code compliance with fossil-fuel-heated single-family homes. When windows as energy-efficient as those commonly used in new homes are assumed, the economic impacts of the MEC can be much smaller--the construction cost increase goes down by half or more and the energy savings also go down. 


\section{Contents}

Summary $\ldots \ldots \ldots \ldots \ldots \ldots \ldots \ldots \ldots \ldots \ldots \ldots \ldots \ldots \ldots \ldots \ldots \ldots \ldots \ldots \ldots$

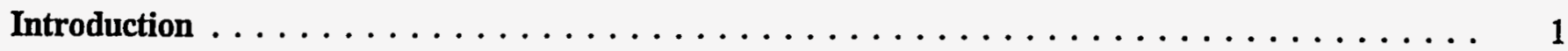

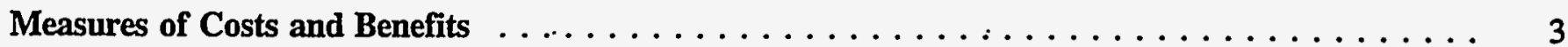

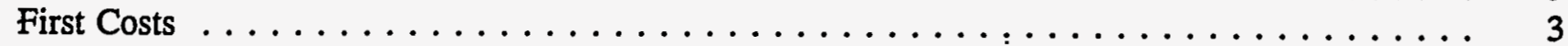

Mortgages: Down Payment, Monthly Payment, and Tax Deductions . . . . . . . . . . . 4

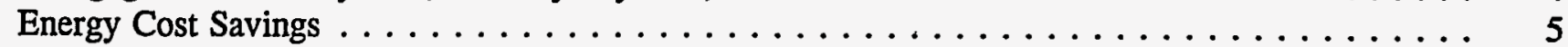

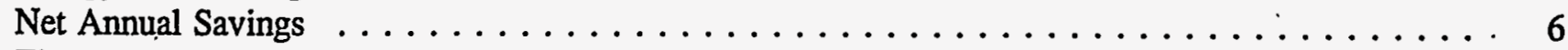

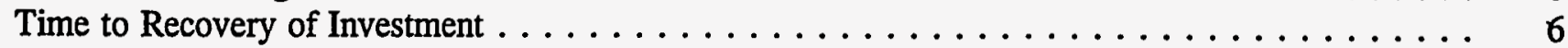

Life-Cycle Costs $\ldots \ldots \ldots \ldots \ldots \ldots \ldots \ldots \ldots \ldots \ldots \ldots \ldots$

Conclusions $\ldots \ldots \ldots \ldots \ldots \ldots \ldots \ldots \ldots \ldots \ldots \ldots \ldots \ldots \ldots \ldots \ldots \ldots \ldots$

Analysis Tool $\ldots \ldots \ldots \ldots \ldots \ldots \ldots \ldots \ldots \ldots \ldots \ldots \ldots \ldots \ldots \ldots$

Financial, Economic, and Fuel-Price Parameters $\ldots \ldots \ldots \ldots \ldots \ldots \ldots \ldots$

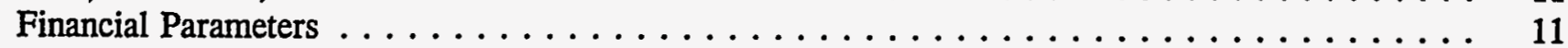

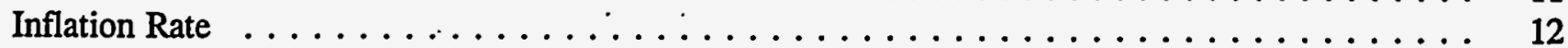

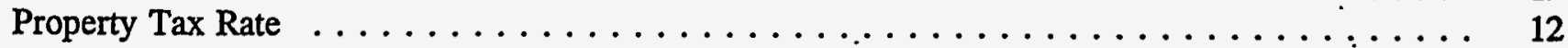

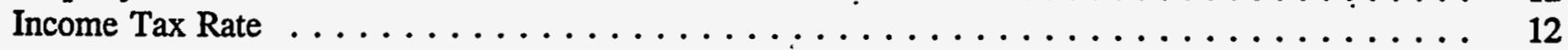

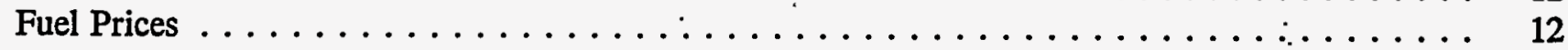

Energy-Efficiency Measures $\ldots \ldots \ldots \ldots \ldots \ldots \ldots \ldots \ldots \ldots \ldots \ldots \ldots$

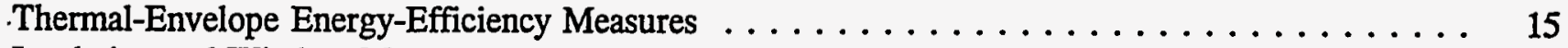

Insulation and Window Measure Costs $\ldots \ldots \ldots \ldots \ldots \ldots \ldots \ldots$

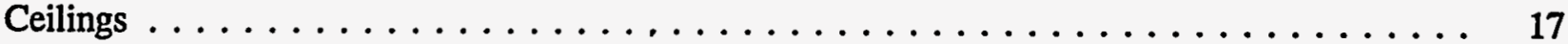

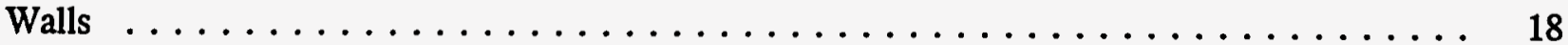

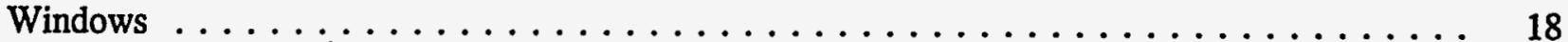

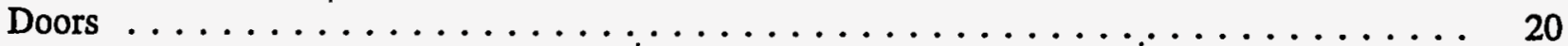

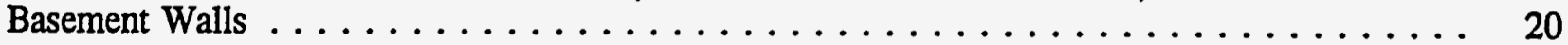

Prototype Dwellings . . . . . . . . . . . . . . . . . . . . . . . 20

Heating, Ventilating, and Air-Conditioning Specifications . . . . . . . . . . . 21

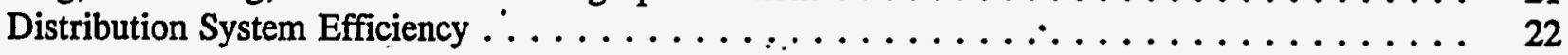

References $\ldots \ldots \ldots \ldots \ldots \ldots \ldots \ldots \ldots \ldots \ldots \ldots \ldots \ldots \ldots \ldots \ldots \ldots \ldots \ldots \ldots$

Appendix A - Results for Electric Resistance Heating $\ldots \ldots \ldots \ldots \ldots \ldots \ldots \ldots$

Appendix B - Measures of Costs and Benefits Relative to Current Practice . . . . . . . . . . . . B.1

Appendix C - Sensitivity of Results to Other Input Parameter Values $\ldots \ldots \ldots \ldots$. . . . . . . C.1 


\section{Figures}

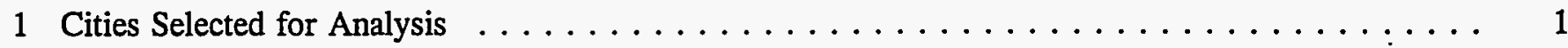

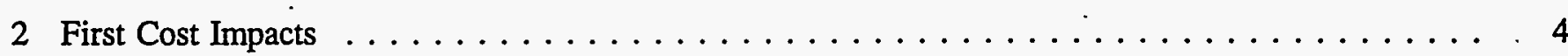

3 Typical Cash Flow for the First Owner of a Single-Family Gas-Heated House in Boston . . . . . . 8

\section{Tables}

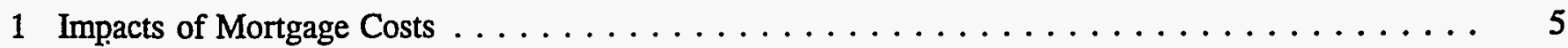

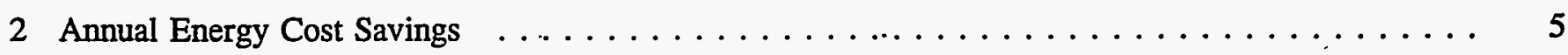

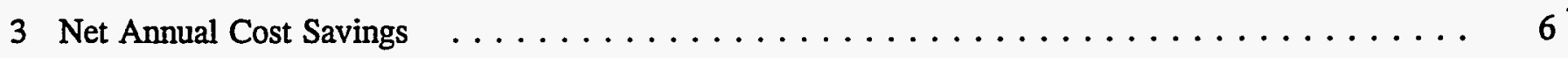

4 Years to Recovery of Investment $\ldots \ldots \ldots \ldots \ldots \ldots \ldots \ldots \ldots \ldots \ldots \ldots \ldots \ldots \ldots \ldots$

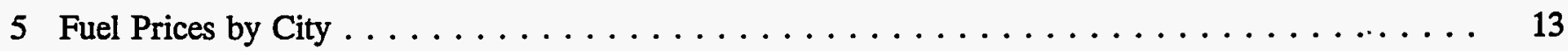

6 Energy-Efficiency Measures for the Massachusetts State Code and 1995 MEC . . . . . . . . . . . 16

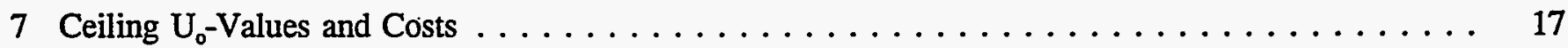

8 Wall $U_{0}-$ Values and Costs $\ldots \ldots \ldots \ldots \ldots \ldots \ldots \ldots \ldots \ldots \ldots$

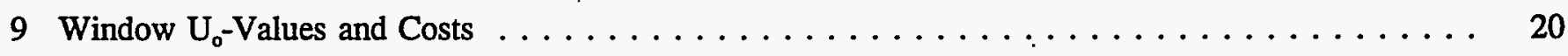

10 Equipment Efficiencies Used in This Analysis . . . . . . . . . . . . . . . . . 22 


\section{Introduction}

This report documents the analysis of the cost effectiveness, in the state of Massachusetts, of the Council of American Building Officials' 1995 Model Energy Code (MEC) (CABO 1995) building thermal-envelope requirements for new residential construction. This analysis was directed by the U.S. Department of Energy's (DOE) Office of Energy Efficiency and Renewable Energy .(Christine Ervin, Assistant Secretary) and was conducted by Pacific Northwest National Laboratory. ${ }^{\text {(a) }}$

This analysis examined the costs and benefits associated with installing the energy-efficiency measures, such as insulation and windows, needed to comply with the requirements of the $1995 \mathrm{MEC}$. These costs and benefits . to the homeowner result from the changes in construction and financing costs and changes in energy costs. The analysis was done for two different scenarios: a "move-up" home buyer purchasing a single-family house and a "first-time" financially limited home buyer purchasing a smaller multifamily unit.

Three Massachusetts cities were selected for this analysis: Boston, Worcester, and Pittsfield. Figure 1 shows the heating degree-days (HDD) for each of the three cities. These three cities were selected to highlight the range of climates in Massachusetts and.the corresponding MEC

requirements. The MEC thermal-envelope requirements are a function of

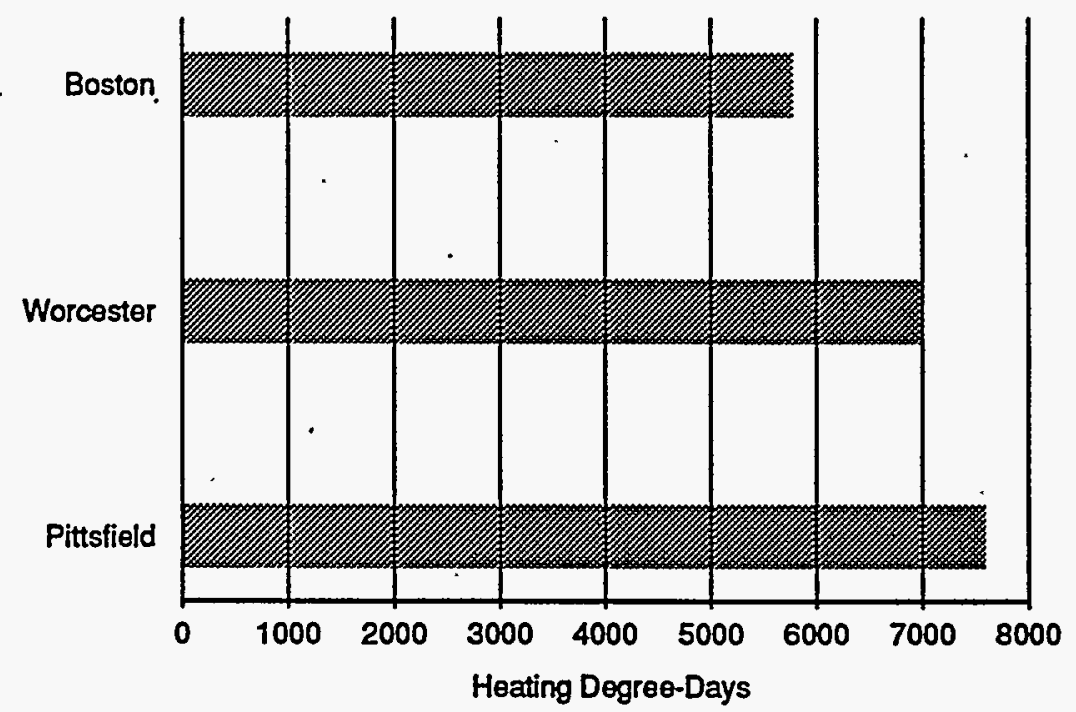

Figure 1. Cities Selected for Analysis

(a) Pacific Northwest National Laboratory is a multiprogram national laboratory operated for the U.S. Department of Energy under Contract

DE-AC06-76RLO 1830 by Battelle Memorial Institute. 
HDDs, a measure of heating season severity. The cities presented here and in the remainder of the report are in order of mildest (Boston) to coldest (Pittsfield) location.

This report is organized as follows. The estimated costs and benefits of the 1995 MEC on homeowners in Massachusetts when gas or oil heat are used are given in the next section. The analysis tool used to estimate the energy consumption impacts is briefly discussed. A discussion of the choice of the financial, economic, and fuel-price parameters used in the analysis of costs and benefits follows. Next, the characteristics and costs of the energyefficiency measures used to comply with the current Massachusetts code and the $1995 \mathrm{MEC}$ are given. The references cited in the text are presented at the end of this report. Appendix A presents results for electric resistance heating. Appendix B shows the economic impacts of the MEC relative to typical current construction practice instead of the minimum requirements of the state code. A sensitivity analysis showing the impacts of key assumptions made in this study is given in Appendix C. 


\section{Measures of Costs and Benefits}

This section presents the findings of the cost/benefit analysis of increasing (or decreasing) energy efficiency in Massachusetts dwellings to the levels necessary to comply with the $1995 \mathrm{MEC}$. The overall results are shown in terms of first cost, mortgage cost impacts, energy cost impacts, and the years to recover the investment. All results reported here are economic impacts from the perspective of the home buyer/owner. Results are shown here for natural gas and oil heating; results for the less common electric resistance heating are shown in Appendix A. It is important to stress this report analyzed the incremental costs and benefits resulting from increasing energy-efficiency levels from the levels needed for compliance with the current Massachusetts code to the levels needed for compliance-with the 1995 MEC.

It is likely that most new housing in Massachusetts exceeds some of the requirements of the current state code, so the results presented here represent the upper limit of the impacts of compliance with the MEC. Most notably, the current state code normally allows any type of double-paned windows, and the current practice in most new houses is to have much more energy-efficient windows than those assumed here in some instances for state code compliance. Appendix B shows the economic impacts of compliance with the MEC relative to current practice instead of the statecode minimums.

\section{First Costs}

The first cost is the incremental retail cost to purchase and install energy features in the house; for example, the cost to buy and install more insulation. This cost includes the builder's profit. This is the cost that would be paid if the dwelling were paid for in cash.

Figure 2 compares the increase in first costs (assuming no mortgage) from the construction changes needed for compliance with the $1995 \mathrm{MEC}$ for both the single-family and the multifamily home buyer. The MEC will generally increase first costs more in colder locations because the MEC is more stringent in these locations while the state code does not vary by location. An exception to this is seen for single-family homes in Pittsfield compared to Worcester. Pittsfield is slightly colder than Worcester. However, the MEC requirements are almost identical for these two cities, and therefore the same energy conservation measures are assumed for MEC compliance in Pittsfield and Worcester. Because construction costs are assumed to be lower in Pittsfield (see page 17), the first cost increase is slightly lower in Pittsfield than in Worcester. Much of the first cost increase from the MEC for the single-family home buyer is attributable to the cost of highly energy-efficient low-emissivity windows assumed in this analysis. 


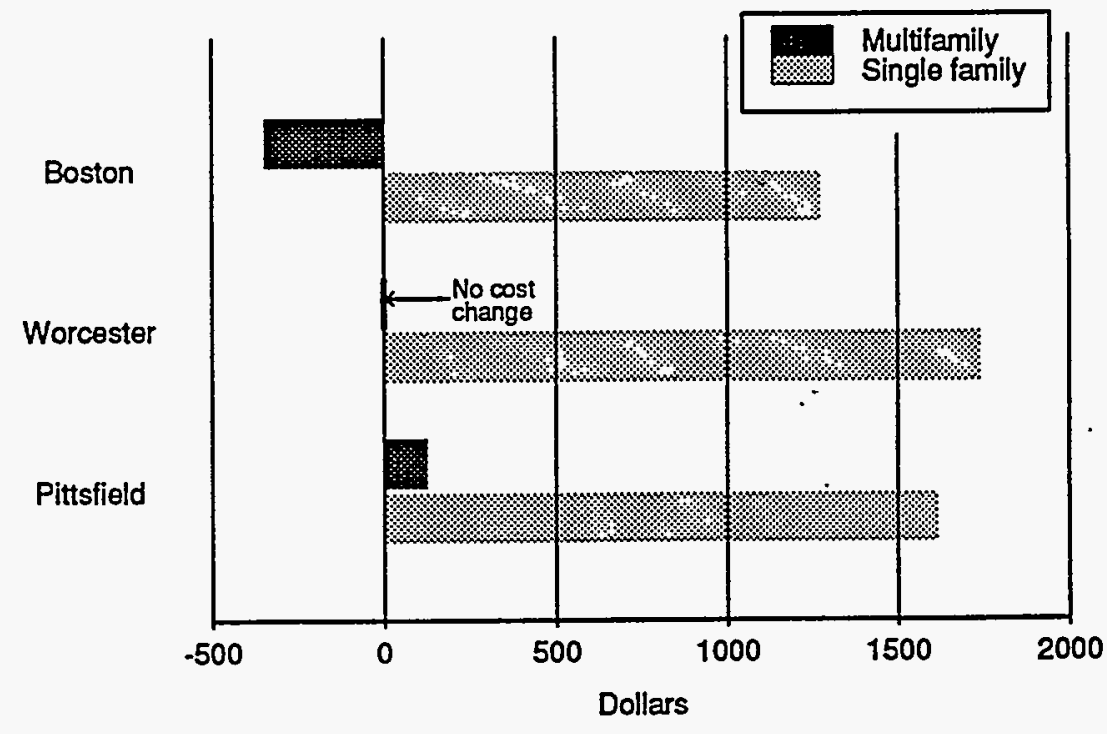

Figure 2. First Cost Impacts

In the MEC, the envelope requirements for walls are less stringent for multifamily units than for single-family houses. The result of this is that the stringency of the MEC multifamily requirements is very comparable to the Massachusetts code for the multifamily building examined here. In Boston, the state code is actually more stringent than the MEC.

Mortgages: Down Payment, Monthly Payment, and Tax Deductions
Because most houses are financed, the financial impacts of the 1995 MEC on mortgages will likely be of significant interest to the consumer. This report deals with a single-family home buyer making a down payment of $20 \%$ of the loan amount and a more financially limited buyer of a multifamily unit making a down payment of $10 \%$ of the loan amount. Mortgage payments are constant over the period of the mortgage, and the interest portion of the payments is assumed to be deducted from income taxes. An adjustable-rate mortgage might result in different costs to the home buyer, but this type of mortgage is not examined here because of its unpredictable nature.

Table 1 shows how mortgage-related costs will be impacted for a 30-year fixed-rate mortgage. The up-front costs include the down payment, points, and loan fees. The savings from income tax deductions of the mortgage interest will slowly decrease over time, and the values shown in Table 1 are for the first year: Negative numbers indicate MEC compliance will decrease mortgage costs because the MEC is less stringent than the state code. 
Table 1. Impacts of Mortgage Costs

\begin{tabular}{||l|c|c|c||}
\hline \multirow{2}{*}{} & \multicolumn{3}{|c||}{ Cost Change Per Housing Unit } \\
\cline { 2 - 4 } & Boston & Worcester & Pittsfield \\
\hline \hline Annual mortgage payment increase & & & \\
Single family & $\$ 94$ & $\$ 128$ & $\$ 119$ \\
Multifamily & $-\$ 28$ & $\$ 0$ & $\$ 10$ \\
\hline Up front cost increase & & & \\
Single family & $\$ 268$ & $\$ 366$ & $\$ 340$ \\
Multifamily & $-\$ 39$ & $\$ 0$ & $\$ 14$ \\
\hline First year tax deduction savings & & & $\$ 37$ \\
Single family & $\$ 27$ & $\$ 0$ & $\$ 2$ \\
Multifamily & $-\$ 5$ & & $\$ 34$ \\
\hline
\end{tabular}

Energy Cost Sàvings
Ensuring reasonably low energy cost (i.e., the homeowner's utility bill for heating and cooling) is the major benefit of any building energy-efficiency code or standard. The intent of the $1995 \mathrm{MEC}$ is to "enable effective use of energy in new building construction" (CABO 1995).

Table 2 shows the estimated energy cost changes by heating fuel/equipment type resulting from the changes in levels of energy efficiency resulting from the MEC. Energy cost savings are higher for natural gas than for oil because-natural gas is more expensive. As might be expected, the energy cost savings from the MEC are larger in the colder climates than in the milder climates. Because compliance with the MEC for multifamily buildings requires only minor changes, the energy cost changes are relatively low. Because the state code is slightly more stringent than the MEC for the multifamily building in Boston, Table 2 shows negative energy cost savings (i.e., an energy cost increase) from meeting (but not exceeding) the MEC requirements.

Table 2. Annual Energy Cost Savings

\begin{tabular}{||l|l|c|c|c||}
\hline \multirow{2}{*}{} & \multicolumn{4}{|c|}{ Cost Change Per Housing Unit } \\
\cline { 2 - 5 } & \multicolumn{1}{|c|}{$\begin{array}{c}\text { Heating } \\
\text { Fuel Type }\end{array}$} & Boston & Worcester & Pittsfield \\
\hline \hline Single family & Natural gas & $\$ 243$ & $\$ 336$ & $\$ 425$ \\
& Oil & $\$ 179$ & $\$ 238$ & $\$ 274$ \\
\hline Multifamily & Natural gas & $-\$ 46$ & $\$ 0$ & $\$ 29$ \\
& Oil & $-\$ 33$ & $\$ 0$ & $\$ 19$ \\
\hline
\end{tabular}

It should be noted that the annual energy cost savings in Table 2 are for the initial fuel prices. The energy cost changes are expected to increase in the future because energy prices are expected to rise. Air conditioning is 


\section{Net Annual Savings}

Time to Recovery of Investment assumed only in Boston, and most of the energy cost savings are from heating season energy savings (see Appendix $C$ for more information on the share of energy cost changes that result from cooling costs).

Table 3 shows the net annual savings, including energy costs, mortgage payments, property tax, and mortgage tax deduction, but not including the . up-front costs.

Table 3. Net Annual Cost Savings

\begin{tabular}{||l|l|c|c|c||}
\hline \multirow{2}{*}{} & \multicolumn{3}{|c|}{ Cost Change Per Housing Unit } \\
\cline { 2 - 5 } & \multicolumn{1}{|c|}{$\begin{array}{c}\text { Heating } \\
\text { Fuel Type }\end{array}$} & Boston & Worcester & Pittsfield \\
\hline \hline Single family & Natural gas & $\$ 164$ & $\$ 229$ & $\$ 325$ \\
& Oil & $\$ 100$ & $\$ 131$ & $\$ 175$ \\
\hline Multifamily & Natural gas & $-\$ 19$ & $\$ 0$ & $\$ 20$ \\
& Oil & $-\$ 6$ & $\$ 0$ & $\$ 10$ \\
\hline
\end{tabular}

Most consumers want to know when they will start saving money (accounting for all costs and benefits). The energy cost savings resulting from increased energy efficiency start as soon as the dwelling is occupied. Of more interest may be the time when the consumer has saved more money than he or she has paid out (including the down payment). This is referred to as the time to recovery of investment. Beyond this time, the net cost savings can be expected to continue to grow; thus, the shorter the length of time to the recovery of investment, the more attractive investing in increased energy efficiency becomes.

Table 4 shows the number of years until the homeowner realizes a net cost savings from the increased levels of energy efficiency (i.e., the cumulative savings exceeds the cumulative expenditures). This length of time was derived from the calculation of the up-front costs, mortgage payments, energy costs, property tax, and mortgage interest tax deductions. For example, during the second year of ownership, a single-family homeowner in Boston with natural gas heat would have saved more money than expended, and the savings would continue to grow after that time. Note that the recovery of investment occurs in three years or less in all cases. The years to the recovery of investment for compliance with the MEC for Boston and Worcester multifamily buildings is not applicable because the MEC does not exceed the state code and, therefore, there is no "investment". 
Table 4. Years to Recovery of Investment

\begin{tabular}{||l|l|c|c|c||}
\hline & \multicolumn{1}{|c|}{ Heating } \\
& Fuel Type & Boston & Worcester & Pittsfield \\
\hline \hline Single family & Natural gas & 2 & 2 & 2 \\
& Oil & 3 & 3 & 2 \\
\hline Multifamily & Natural gas & - & - & 1 \\
& Oil & - & - & 2 \\
\hline
\end{tabular}

An instructive method of looking at the costs and benefits of increased investments in energy efficiency is by analyzing the cash flow over time. Figure 3 shows the cumulative cash flow for a typical first owner of a single-family house in Boston with natural gas heating. The figure shows the cash flow for a dwelling built to the efficiency levels required by the 1995 MEC relative to a dwelling built to comply with the Massachusetts state code. A 30-year mortgage and a $20 \%$ down payment were assumed. Lines with annual changes in property taxes and mortgage deductions are not shown on the plot but are included in the total savings. The owner is assumed to sell the house after 7 years, at which time the mortgage is terminated. At the time of the purchase, there is a cost of $\$ 268$ to cover the increased down payment and other up-front cost increases. Because the energy cost savings exceed the mortgage payment increases, the net cash flow for each year is positive (excluding the first year, which has the upfront costs). At the end of 7 years when the house is sold, the estimated resale value exceeds the mortgage termination cost related to the additional investment in energy efficiency by $\$ 129$. so the total savings increases from $\$ 1074$ to $\$ 1203$ at the time of sale. The resale value is based on uninflated

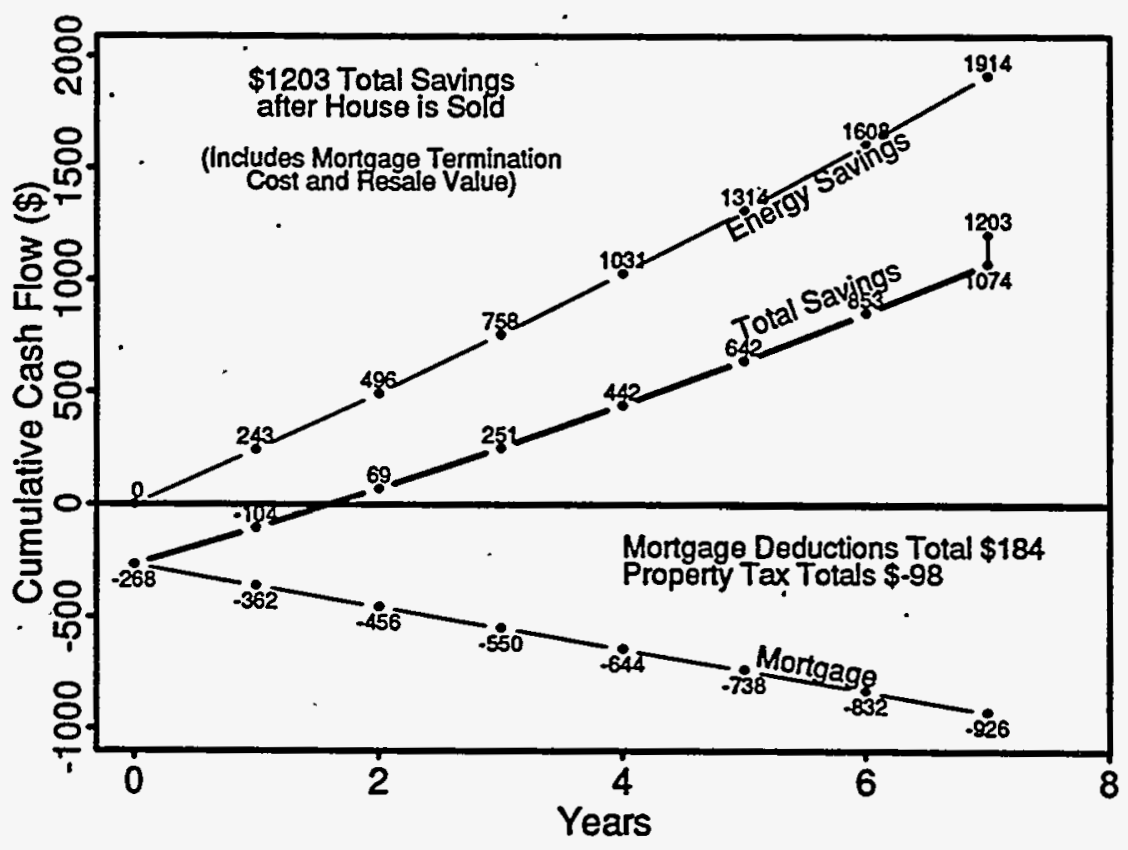

Figure 3. Typical Cash Flow for the First Owner of a Single-Family Gas-Heated House in Boston 


\section{Life-Cycle Costs}

straight-line depreciation. The cumulative cash flow becomes positive during the second year and continues to grow in all future years. Note that if the first owner sells the house, any future owner will also quickly obtain a recovery of investment. The cash flow from increased efficiency for future owners is even more favorable than the cash flow for the first owner because depreciation causes the share of the purchase cost related to the energy-efficiency measures to decrease, and likely future fuel cost increases cause energy cost savings to increase.

The number of buyers impacted by the increased first cost can be estimated. The National Association of Home Builders (NAHB) estimated that a cost increase of $\$ 1680$ required an additional $\$ 570 /$ year in buyer income and disqualified 2.5\% of the potential home buyers (Consumers' Research 1991). For a Boston single-family house, this was scaled back to the estimated first cost increase of $\$ 1273$, producing an estimate that the energy-efficiency standards would require an additional $\$ 432$ in family income and potentially disqualify approximately $1.9 \%$ of the prospective new home buyers. This calculation assumes that no credit is given in the mortgage process for reduced homeowner expenses resulting from a reduction in energy cost. "Stretch" mortgages, which allow an increase in the mortgage for investments in energy-efficiency to meet codes such as the MEC or other efficiency targets, are becoming. common. The minimal cost impacts on the buyer of a multifamily unit should have very little affect the mortgage qualification process.

All the results shown to this point are over the short term. An economic measure of long-term investments that is commonly used is the life-cycle cost. The life-cycle cost is the present value of all costs and benefits, with future costs and/or benefits discounted to account for the lower value of money in the future relative to the present. With a 30-year period of analysis and a $4.0 \%$ real discount rate, the present value of life-cycle cost savings from compliance with the $1995 \mathrm{MEC}$ for the single-family house vary from $\$ 983$ for an oil-heated house in Boston to $\$ 3471$ for a gas-heated house in Pittsfield.

\section{Conclusions}

The 1995 MEC requires more stringent energy-efficiency levels than Massachusetts state code for single-family homes. Compliance with the MEC was estimated to increase first costs by between $\$ 1273$ and $\$ 1738$. The time when the homeowner realizes a recovery of investment for singlefamily houses built in accordance with the MEC was 2 to 3 years. Thereafter, the "investment" continues to provide a positive cash flow.

For multifamily buildings, the $1995 \mathrm{MEC}$ has requirements that are about the same stringency as the state code; in fact, the state code is more stringent in the Boston area. In colder parts of the state, the 1995 MEC may result in modest increases in first costs and decreases in energy costs for multifamily dwellings. 


\section{Analysis Tool}

This analysis utilized the energy database in the Automated Residential Energy Standard (ARES) program. The ARES software is a computer program developed for-DOE that contains an economic methodology for residential energy-efficiency decisions (Lortz and Taylor 1989). Given a set of fuel-price, financial, economic, and energy-efficiency measure cost parameters for a building at a specific location, ARES identifies the economic impacts of incremental improvements in energy efficiency. ARES considers both space heating and cooling, and is designed specifically for residential energy-efficiency analyses.

In addition to an economic analysis model, ARES incorporates an energy database produced by a simulation model, allowing the software to estimate the energy use for a specific selection of insulation and window measures. The energy usage associated with each combination of measures becomes an input to the ARES economic analysis. The incorporation of an energy simulation in ARES removes the requirement for doing separate building energy simulations. The ARES energy simulation is a parameterization of a large database of DOE-2 simulations (DOE 1989a) (DOE-2 is a sophisticated energy-analysis software commonly used to estimate building energy consumption). 



\section{Financial, Economic, and Fuel-Price Parameters}

In this section, the financial, economic, and fuel-price-parameter values necessary for the cost/benefit analysis of the $1995 \mathrm{MEC}$ are specified, justified, and documented. Most of the financial, economic, and fuel-price parameters required for input to this analysis are summarized below. These parameters are used to calculate the costs and benefits from the homeowner's perspective.

- new home mortgage parameters

- mortgage interest rate $(8.0 \%)$

- points and loan fees (1.6\% of the mortgage amount)

- loan term (30 years)

- down payment (20\% for single-family, $10 \%$ for multifamily)

- other rates and economic parameters

- marginal federal plus state income tax rates (33\% for single-family, $20 \%$ for multifamily)

- property tax (1.4\%)

- residential fuel prices by city (see page 13 ).

In choosing the parameters for the analysis, the intent was to identify and document the best source available for each parameter. Most of the parameter values are commonly reported statistics and are traceable to other published sources. It should be noted that some of the parameter values vary across time, locations, markets, institutions, circumstances, and/or individuals.

\section{Financial Parameters}

Because most home buyers obtain a mortgage, the economic analysis accounts for a mortgage. A mortgage interest rate of $8.0 \%$ was selected for this analysis--this is approximately equal to rates during the past year (NAHB 1995) and long-term average rates (OTS 1991). Points and loan fees were assumed to be $1.6 \%$ of the mortgaged amount; this is based on long-term U.S. Office of Thrift Supervision historical real averages using 1963-1991 data (OTS 1991). The up-front mortgage costs were assumed to be split equally between points (tax deductible) and loan fees (not tax deductible).

The 30-year mortgage term is the most typical; therefore, 30 years was the loan term for this analysis.

A down payment of $20 \%$ of the mortgage amount was used for the singlefamily home buyer. A down payment of $\mathbf{1 0 \%}$ was used for the multifamily unit to represent the lower down payment commonly paid by a financially limited first-time home buyer. 
Private mortgage insurance is normally required for loans without large down payments. Based on data provided by a mortgage company, the NAHB (1992)-developed data, and various types of loans and down payments commonly available, average private mortgage insurance costs were calculated. Private mortgage insurance was included as a non-taxdeductible cost to the home buyer, fixed at $3.5 \%$ of the mortgage loan amount, and included in the mortgage payments. It should be noted that many home buyers do not need private mortgage insurance.

\section{Inflation Rate}

Property Tax Rate

DOE's Energy Information Administration projects a general, nominal annual inflation rate of $3.9 \%$ (EIA 1993). This rate is equal to the average forecast of four other sources (EIA 1993). This inflation rate is used to account for the expected increase in future fuel costs. As fuel costs are assumed to increase at the same rate of all other goods and services, the "real" fuel escalation rate is assumed to be zero. Note that, over the short term, the impact of the inflation rate is small.

Income Tax Rate

For this analysis, there was assumed to be a property tax of $1.4 \%$ of the dwelling's value. Therefore, the homeowner must pay $1.4 \%$ of the change in first costs resulting from compliance with the 1995 MEC. This typical tax rate for Massachusetts was determined from an article in Money (1992).

The marginal income tax rate paid by the homeowner determines the value of the mortgage tax deduction. The homeowner is assumed to itemize deductions, which is most common. For the single-family home buyer, the marginal income tax rate was assumed to be $28 \%$. Because the multifamily scenario focuses on the low- to medium-income home buyer, the marginal income tax rate was assumed to be $15 \%$. Accounting for a state income tax rate of 5\% (Conner and Lucas 1994), the total income tax rate used for the single-family and the multifamily analyses was $33 \%$ and $\mathbf{2 0 \%}$, respectively.

\section{Fuel Prices}

From the consumer's perspective, the energy cost savings from changes in energy-efficiency levels are driven by marginal fuel prices, which may not equal average fuel prices. For example, utilities often charge a lower rate per kilowatt hour of electricity for additional consumption beyond some minimum threshold--the marginal rate is this lower rate. Because changes in energy consumption resulting from complying with the 1995 MEC instead of the Massachusetts state code will be at the margin, marginal fuel prices were used in the analysis. Residential energy prices were obtained by calling the local gas and electric utilities and local companies that provide heating oil. The fuel prices used in the analysis are shown in Table 5. 
Table 5. Fuel Prices by City ${ }^{(2)}$

\begin{tabular}{|l|c|c|c|c||}
\hline \multirow{2}{*}{ City } & \multirow{2}{*}{$\begin{array}{c}\text { Natural Gas } \\
(\$ / \text { therm })\end{array}$} & $\begin{array}{c}\text { Fuel Oil } \\
\cdot(\$ / \text { gal })\end{array}$ & Heating & Cooling \\
\cline { 3 - 5 } & 0.903 & 0.899 & 0.115 & 0.115 \\
Boston & 0.703 & 0.69 & 0.0720 & - \\
Worcester & 0.849 & 0.759 & 0.1076 & - \\
Pittsfield & (a) These are marginal fuel prices. \\
\hline \hline
\end{tabular}





\section{Energy-Efficiency Measures}

Thermal-Envelope Energy-Efficiency Measures
The analysis to determine the cost effectiveness of the MEC in Massachusetts requires information on the costs of insulation and window measures needed to meet the Massachusetts code and the 1995 MEC. This section primarily documents the characterization of the measures used in the analysis, including the thermal ratings (R-values for the ceilings, abovegrade opaque walls, and basement walls; U-values for windows); costs; and the construction assumptions.

This economic analysis considers the cost effectiveness of the MEC thermal-envelope requirements. The envelope components considered in the analysis are ceilings, above-grade opaque walls, windows, doors, and basements with wall insulation. Basements are the most common foundation type in Massachusetts residences; basements with ceiling insulation are examined in Appendix C. Table 6 shows insulation levels and.window types corresponding to the Massachusetts state code and 1995 MEC compliance for the single-family and multifamily dwellings.

The MEC and Massachusetts state code generally specify thermal-envelope requirements in terms of overall component $U$-value, which is called the $\mathrm{U}_{\mathrm{o}}$-value. A U-value is the inverse of the R-value, and a:lower $\mathrm{U}$-value represents higher energy efficiency. In the $\mathrm{MEC}$, the $\mathrm{U}_{\mathrm{o}}$-value accounts for all materials in the component, including gypsum board, framing, insulation, and siding (framing is ignored in the Massachusetts state code $\mathrm{U}$-value requirements). Components include ceilings, above-grade walls, and various foundation types. The MEC does not specify window, door, or opaque wall thermal requirements individually, but rather specifies gross wall $U_{0}$-value requirements. The Massachusetts state code has separate requirements for opaque walls, windows, and doors. The MEC requirements vary by $\mathrm{HDD}$, while the Massachusetts state code has a single set of requirements for the entire state.

It should be noted that compliance with the $1995 \mathrm{MEC}$ and the state code can be based on meeting individual component $U_{0}$-value requirements, by meeting an equivalent overall building $U_{0}$-value (as was done for this analysis), or by an energy-consumption-based performance approach. Thus, a number of alternative combinations would lead to compliance for any particular dwelling. For this analysis, combinations of measures complying with the MEC shown in Table 6 were selected utilizing software known as "MECcheck" (PNL 1995). This software notifies the user if a set of insulation and window measures complies with the MEC and allows trade-offs across all building components. Note that the energy-efficiency measures for the MEC in Table 6 below do include some trade-offs that are allowed by Section 502.1.1 in the MEC. For example, in Boston, the R-30 ceiling insulation will not meet the roof/ceiling $U_{0}$-value requirement shown on page 37 of the MEC. This is compensated for, however, by the energyefficient windows. 
Table 6. Energy-Efficiency Measures for the Massachusetts State Code and 1995 MEC

\begin{tabular}{|c|c|c|c|c|}
\hline & $\begin{array}{l}\text { Ceiling } \\
\text { Insulation }\end{array}$ & $\begin{array}{c}\text { Wall } \\
\text { Insulation }\end{array}$ & $\begin{array}{c}\text { Window U-value and } \\
\text { Type }\end{array}$ & $\begin{array}{l}\text { Basement } \\
\text { Insulation }\end{array}$ \\
\hline \multicolumn{5}{|c|}{ Massachusetts State } \\
\hline Single family & $\mathrm{R}-30$ & $\mathrm{R}-11$ & $\begin{array}{l}\mathrm{U}-0.72 \text {, Double } \\
\text { aluminum }\end{array}$ & R-11 \\
\hline Multifamily & $\mathrm{R}-30$ & $\mathrm{R}-11$ & $\begin{array}{l}\text { U- } 0.50 \text {, Double vinyl or } \\
\text { wood }\end{array}$ & R-11 \\
\hline \multicolumn{5}{|l|}{$1995 \mathrm{MEC}$} \\
\hline $\begin{array}{l}\text { Boston } \\
\text { Single family }\end{array}$ & $\mathrm{R}-30$ & $\mathrm{R}-13$ batt & $\begin{array}{l}\text { U- } 0.38 \text {, Double vinyl or } \\
\text { wood, with low-E }\end{array}$ & $\mathbf{R}-11$ \\
\hline Multifamily & $\mathrm{R}-30$ & R-11 batț & $\begin{array}{l}\text { U-0.68, Double } \\
\text { aluminum } \\
\text { (a) }\end{array}$ & R-11 \\
\hline Worcester & & & & \\
\hline Single family & $\mathrm{R}-38^{(\mathrm{b})}$ & $\begin{array}{l}\mathrm{R}-13 \text { batt }+ \\
\mathrm{R}-4 \text { sheathing }\end{array}$ & $\begin{array}{l}\text { U- } 0.34 \text {, Double vinyl or } \\
\text { wood, with low-E and } \\
\text { argon }\end{array}$ & $\mathrm{R}-11$ \\
\hline Multifamily & R-30 & $\mathrm{R}-11$ batt & $\begin{array}{l}\text { U-0.50, Double vinyl or } \\
\text { wood }\end{array}$ & $\mathrm{R}-11^{\circ}$ \\
\hline Pittsfield & & & & \\
\hline Single family & $\mathrm{R}-38^{(\mathrm{b})}$ & $\begin{array}{l}\mathrm{R}-13 \text { batt }+ \\
\mathrm{R}-4 \text { sheathing }\end{array}$ & $\begin{array}{l}\text { U-0.34, Double vinyl or } \\
\text { wood, with low-E and } \\
\text { argon }\end{array}$ & R-11 \\
\hline Multifamily & $\mathrm{R}-30$ & R-11 batt & $\begin{array}{l}\text { U- } 0.38 \text {, Double vinyl or } \\
\text { wood, with low-E }\end{array}$ & $\mathrm{R}-11$ \\
\hline
\end{tabular}

Combinations of measures other than those shown in Table 6 could also be selected for both the state code and the MEC. Both codes allow any tradeoff as long as the energy consumption is not increased. If the heating, ventilating, and air-conditioning (HVAC) equipment efficiencies are above the minimums assumed in this analysis (the minimums allowed by Federal law were assumed here), reductions in the energy efficiency of the envelope levels may be possible. As just one example, if a $90 \%$ efficient gas furnace is used in the Boston single-family house, low-E coatings are not needed on the windows and also approximately $70 \mathrm{ft}^{2}$ more windows can be installed, and compliance with the MEC is still achieved. 
Insulation and Window Measure Costs
Having established insulation and window measures that comply with the Massachusetts state energy code and the 1995 MEC, the next step was to determine construction costs for each of these measures. The costs of interest are those for the improvement (or decrease) in energy efficiency to move from the levels needed for compliance with the state code to the levels needed for MEC compliance. All costs in the tables in this section represent national average retail costs to the home buyer/owner. These costs include materials, installation, and markups for overhead and profit. Cost data were modified to account for higher construction costs in Massachusetts, using location factors reported by Means (1994). These factors increased national prices by $20 \%$ for Boston, $13 \%$ for Worcester, and 5\% for Pittsfield. These location adjustments increase the national average costs shown in the following sections. Costs from older sources were inflated to current conditions based on the residential construction cost inflation rate (DOC 1992, 1995).

Component $U_{0}$-values are also presented in the following sections. $\mathrm{U}_{\mathrm{o}}$-values affect compliance with the Massachusetts code and the 1995 MEC and closely relate to energy use (note that the $U_{0}$-values presented here account for framing whereas $\mathrm{U}_{0}$-value requirements in the Massachusetts state code ignore framing). The $\mathrm{U}_{\mathrm{o}}$-values used here were determined using material thermal properties and calculation techniques recommended by ASHRAE (1993). Window $U_{0}$-values were obtained from tested window data.

Ceilings were assumed to have an attic space; vaulted ceilings/roofs were not considered. Dwellings with vaulted ceilings may have to have lower levels of insulation in the vaulted section and, therefore, would require slightly higher levels elsewhere. No skylights were assumed. Cost data for ceiling-insulation levels and construction assemblies were obtained from two national sources:

- Means Residential Cost Data-1995 (Means 1994)

\section{- 1995 National Construction Estimator (Craftsman 1994)}

Table 7 shows the $U_{0}$-values and costs for roof/ceiling-insulation $R$-values used in this analysis. The costs are for regular-density fiberglass batt insulation. Cost data for $R-49$ was not available; this cost was obtained by linear extrapolation of the R-30 to R-38 cost.

Table 7. Ceiling $U_{0}$-Values and Costs

\begin{tabular}{|c|c|c||}
\hline Nominal R-Value & Ceiling $U_{\mathrm{o}}$-Value & $\begin{array}{c}\text { Cost Relative to } \\
\text { R-11 }\left(\$ / \mathrm{ft}^{2}\right) \ldots\end{array}$ \\
\hline \hline R-30 & 0.0353 & 0.36 \\
R-38 & 0.0300 & 0.52 \\
R-49 & 0.0259 & 0.74 \\
\hline
\end{tabular}


The wall insulation assumed for compliance with the Massachusetts state code was R-11 insulation in a 2 by 4 16-in. on-center framed wall with plywood sheathing. Compliance with the $1995 \mathrm{MEC}$ was achieved by a combination of R-11 or R-13 wall insulation and, in some cases, foam sheathing insulation. Table 8 shows the wall-insulation measures, $\mathrm{U}_{\mathrm{o}}$-values, and cost increments used in this analysis in order of decreasing $\mathrm{U}_{\mathrm{o}}$-value.

The addition of foam sheathing is a commonly available option, as evidenced by the Means cost data (Means 1994), the Energy Crafted Homes data (Fryer and Schalch 1992), Residential Construction Demonstration Project data (Barnett and Thor 1990), and Builder Magazine (NAHB 1991a). Walls with rigid foam insulation lack structural support and, therefore, need let-in corner bracing. These bracing costs were obtained from Means (1994) and were $\$ 0.13 / \mathrm{ft}^{2}$ of wall area for 16 -in. on-center construction. Walls with plywood at the corners can be used instead of the let-in bracing (plywood corner bracing was assumed in the wall $\mathrm{U}_{\mathrm{o}}$-value calculations). The Means data indicated the cost of the R-4 insulation including corner bracing.is lower than the wood-based sheathing material (such as oriented strand board) it would replace. However, this potential cost reduction cannot be expected to occur solely because MEC compliance is required, so, to be conservative, the incremental cost of the R-4 insulation was assumed to be zero.

Table 8. Wall $U_{0}-$ Values and Costs

\begin{tabular}{|c|c|c|c|}
\hline $\begin{array}{c}\text { Nominal Batt } \\
\text { Insulation R-Value }\end{array}$ & $\begin{array}{c}\text { Rigid Insulation } \\
\text { R-Value }\end{array}$ & $\begin{array}{c}\mathrm{U}_{\mathrm{o}} \text {-value } \\
\text { of Wall }\end{array}$ & $\begin{array}{c}\text { Cost Relative to } \\
\mathrm{R}-11\left(\$ / \mathrm{ft}^{2}\right)\end{array}$ \\
\hline \hline 11 & 0.83 & 0.0892 & 0.00 \\
13 & 0.83 & 0.0823 & 0.07 \\
13 & 4 & 0.0674 & 0.07 \\
15 & 7 & 0.0554 & 0.42 \\
\hline (a) The R-value of 0.83 is for plywood sheathing. \\
\hline
\end{tabular}

Windows

Window cost data were obtained in a manner and from sources different than the insulation cost data. The most important aspect of collecting window cost data is to correctly associate a cost and a $U_{\mathrm{o}}$-value. Obtaining a cost-versus-energy-efficiency relationship is more difficult for windows because window costs are greatly affected by nonenergy characteristics, such as appearance. Obtaining window-efficiency costs is made more difficult by the relatively rapid changes in window technology and energyefficiency costs. In particular, vinyl framing, low-emissivity (low-E) coatings, and argon-filled windows are rapidly penetrating the market and are dropping in price. 
Two sources of window cost data were judged to be the best available. The first was a survey of nine Pacific Northwest window manufacturers for the Washington State Energy Office (Byers 1990). The other source of window cost data was the work done for the California Energy Commission by Eley Associates (1991). A number of reasons dictated the use of these two sources. Foremost was costs for a fairly extensive set of window types were available from multiple manufacturers from both of these sources. (In all cases, there were three or more manufacturers from each of the two sources for each window improvement option of interest.) The data included new energy-efficient technologies, such as vinyl frames, low-E surfaces, and argon gas.

The examination of windows currently in the market from an energyefficiency standpoint showed that the range of costs and efficiencies for the most cost-effective windows could be represented with incremental prices for only a few energy-related features. The incremental changes in windows needed for costing were the addition of low-E coating and the addition of argon gas to double-paned windows. To isolate cost changes for improved energy efficiency, the cost changes for incremental window improvements (such as adding low-E) were determined separately for each manufacturer, so that cost changes were not aggregated across manufacturers until after the cost changes had been identified for each manufacturer. Examining window improvements by manufacturer tended to avoid the large variation in other window characteristics that affect price in intermanufacturer comparisons. The costs for any given incremental thermal improvement were assumed to be constant regardless of other thermal characteristics. For example, the costs of adding a low-E coating to vinyl- and wood-framed windows should be very similar. Further, the W.ashington and California costs were averaged for each window feature. The window costs in both the Washington and California data were the total costs as sold by the manufacturer to mid-sized builders. Installation costs and contractor profit were added to these costs.

Current costs for low-E coatings were difficult to establish because of recent technology improvements. For this reason, the Washington (Byers 1990) or California (Eley 1991) cost data were not used; instead, an estimated cost that was lower was used. In the last few years, there has been a change in the commercially available low-E technologies. Of most interest here is the new "hardcoat" low-E coating, which is both better in performance and lower in price than older "hardcoat" technologies. This new low-E technology has begun to reach the market and was assumed to be the most cost-effective type of coating. The cost of the new low-E coatings to the glass manufacturer is low, approximately $\$ 0.50 / \mathrm{ft}^{2}$ (Gerhardinger and Flagg 1992). Based primarily on this manufacturer's cost, the retail cost (including overhead and profit) of the new low-E coating was estimated to be $\$ 1.00 / \mathrm{ft}^{2}$ to the consumer.

The costs to the consumer for filling window cavities with argon can vary greatly. Because some manufacturers will install argon and charge no additional cost, the cost for argon fill $\left(\$ 1.10 / \mathrm{ft}^{2}\right)$ used here is conservatively high. 
Window $\mathrm{U}_{\mathrm{o}}$-values had to be established for the types of windows examined here. The window types used in the analysis are shown in Table 9. The $\mathrm{U}_{0}$-values are based on median values of windows given by the National Fenestration Rating Council (NFRC 1994). For each of the three window types included in this analysis, there are at least 98.Council-rated products available. $\mathrm{U}_{0}$-values for available windows vary considerably about these median values. Window costs were assumed to scale linearly with $U_{0^{-}}$ values between and beyond the values shown in Table 9 .

Table 9. Window $\mathrm{U}_{0}$-Values and Costs

\begin{tabular}{||l|c|c||}
\hline \multicolumn{1}{|c|}{ Window/Frame Type } & $\begin{array}{c}\text { Window } \\
\mathrm{U}_{\mathrm{o}}-\text { Value }\end{array}$ & $\begin{array}{c}\text { Cost Relative to Double } \\
\text { Aluminum }\left(\$ / \mathrm{ft}^{2}\right)\end{array}$ \\
\hline \hline Double aluminum & 0.72 & 0 \\
Double vinyl or wood & 0.50 & 2.70 \\
Double vinyl or wood plus & 0.38 & 3.70 \\
low-E coating & & 4.80 \\
Double vinyl or wood plus & 0.34 &. \\
low-E coating and argon &. & \\
\hline
\end{tabular}

Doors

Basement Walls

\section{Prototype Dwellings}

Steel doors with U-values of 0.19 were assumed in all cases. Because no changes in doors was assumed for any scenario, the cost of the doors is not relevant in this analysis.

The foundation type assumed in this analysis was a fully below-grade unfinished basement. Because the same basement wall insulation. levels are assumed for both the MEC and the state code, no cost data for basement wall insulation was needed for this analysis. Compliance with the MEC or the state code can also be achieved by insulating the basement ceiling-See Appendix $\mathrm{C}$ for more information on this option.

To establish economic impacts, prototype dwellings must be established. The key is the surface areas of the exterior envelope.components. The prototype dwellings assumed in this analysis are given below.

A survey of new single-family houses (NAHB 1991b) indicated two-story houses were most common in Massachusetts, with one-story much less common. This same survey indicated the average finished floor area for new houses in Massachusetts was $2240 \mathrm{ft}^{2}$. A survey of 224 new, gasheated homes in Massachusetts (Xenergy 1995) reported a median conditioned floor area of $2114 \mathrm{ft}^{2}$.

A two-story, single-family house, with dimensions of $28 \mathrm{ft}$ wide and $40 \mathrm{ft}$ long, with a conditioned floor area of $2240 \mathrm{ft}^{2}$, was assumed in this analysis: 8-ft-high ceilings; ceiling area (bordering the unconditioned attic) of $1120 \mathrm{ft}^{2}$; gross exterior above-grade wall area of $2176 \mathrm{ft}^{2}$; and basement wall area of $1088 \mathrm{ft}^{2}$. A total door area of $56 \mathrm{ft}^{2}$ (approximately 3 doors) was used (Johnson 1987). 
Heating, Ventilating, and Air-Conditioning Specifications
Windows have much higher $U_{0}$-values than opaque walls. Therefore, the amount of window area has a major effect on the gross wall $U_{0}$-value and, therefore, affects compliance "ith the $1995 \mathrm{MEC}$, and, in some cases, the state code. Houses with higit window areas will need greater levels of energy efficiency to comply with the MEC. The survey of 224 new, gasheated homes mentioned above (Xenergy 1995) reported a median windowto-wall-area percentage of $13.0 \%$. Another survey of new homes in New England indicated a mean window-to-wall area percentage of only $8.4 \%$ (Strategic Utility Market Services 1995). An older source (NAHB 1981) reported a national average of $10.3 \%$ in 1980 . For the single-family . analysis, a conservatively high window area of $14 \%$ of the wall area (305 $\mathrm{ft}^{2}$, or $13.6 \%$ of the conditioned floor area) was assumed. See Appendix C for an analysis of the impact of assuming a smaller window area (10\% of the wall area):

The multifamily prototype was assumed to be a $1300-\mathrm{ft}^{2} 2$-story townhouse in a 6-unit building. Each unit was assumed to be 20 by $32.5 \mathrm{ft}$, with the dimensions of the 6 -unit building being 120 by $32.5 \mathrm{ft}$. Assuming 8 -ft-high ceilings, the average gross exterior wall area per unit is $813 \mathrm{ft}^{2}$.

As with a single-family prototype, the most important multifamily prototype assumption in terms of 1995 MEC compliance is the fraction of wall area that is windows and doors. Because multifamily units often have relatively little exterior wall area, the percentage of the wall that is windows tends to be higher than that for single-family houses. The prototype is assumed to have a window-to-wall area percentage of $20 \%$. This gives $163 \mathrm{ft}^{2}$ of window area, equivalent to $12.5 \%$ of the floor area. The door area is assumed to be $40 \mathrm{ft}^{2}$, which equates to approximately two exterior doors. If the combined window and door area is more the $15 \%$ of the gross wall area, the state code requirement changes to have a maximum overall wall $\mathrm{U}_{\mathrm{o}}$-value of 0.167 for structures heated by oil, gas, or heat pumps. This is why Table 6 shows that the more energy-efficient vinyl or wood windows . are assumed for state code requirements for the multifamily building whereas aluminum windows are adequate for the single-family house.

The heating fuel types and equipment assumed in this analysis are shown in Table 10. Central air conditioning was assumed only in Boston. The minimum efficiency of residential HVAC equipment and water-heating equipment are set by mandatory requirements in the National Appliance Energy Conservation Act of 1987 (NAECA 1987). Because of this law, the HVAC and water-heating efficiency requirements in the $1995 \mathrm{MEC}$ are superseded and will have no impact. The heating and cooling equipment efficiencies in this analysis were set at the minimum levels allowed by the Act, as shown in Table 10.

The effect of heating and cooling equipment downsizing is included automatically in this analysis by the ARES software (DOE 1989b). Smaller heating or cooling loads reduce required equipment capacities, and the equipment cost declines accordingly. This equipment cost change is small. 
Table 10. Equipment Efficiencies Used in This Analysis

\begin{tabular}{|c|c|}
\hline System & Efficiency \\
\hline Natural gas furnace & 0.78 annual fuel utilization efficiency (AFUE) \\
\hline Oil furnace & 0.78 AFUE \\
\hline Air conditioner ${ }^{(a)}$ & 10.0 seasonal energy-efficiency ratio \\
\hline
\end{tabular}

\section{Distribution System Efficiency}

Recent research and field measurements have shown duct losses to be a major inefficiency. A single distribution-efficiency factor for air-ducted systems was used in this analysis. This value was determined by reviewing relevant work from recognized experts in the building science technical community and then contacting the respective authors and discussing their findings in light of the objective. These sources (given in Conner and Lucas 1994) were in reasonable agreement, and average values of $75 \%$ duct efficiency (i.e., $25 \%$ loss) were used in this analysis. 


\section{Réferences}

American Society of Heating, Refrigerating, and Air-Conditioning Engineers, Inc. (ASHRAE). 1993. ASHRAE Handbook, 1993

Fundamentals Volume. Atlanta, Georgia.

Barnett, C., and P. Thor. 1990. Construction Cost Analysis for the Residential Construction Demonstration Project - Cycle II. Bonneville Power Administration, Portland, Oregon.

Byers, D. 1990. The Cost of Energy Efficient Windows in Washington. WAOENG \#89-61, Washington State Energy Office, Olympia, Washington.

Conner, C. C., and R. G. Lucas. 1994. Technical Support Document for Proposed Revision of the Model Energy Code Thermal Envelope

Requirements. PNL-9400, Pacific Northwest National Laboratory, Richland, Washington.

Consumers' Research. September 1991. "The Effect of Higher Prices On Housing Affordability.". p. 12.

Council of American Building Officials (CABO): 1995. Model.Energy Code, 1995 Edition. Falls Church, Virginia.

Craftsman Book Company (Craftsman). 1994. 1995 National Construction Estimator. Carlsbad, California.

Eley Associates (Eley). 1991. Volume 1: Low-Rise Residential Confidence and Sensitivity Study, Life-Cycle Cost Analysis. San Francisco, California.

Energy Information Administration (EIA). 1993. Annual Energy Outlook. DOE/EIA-0383(93), U.S. Department of Energy, Washington, D.C.

Fryer, L., and N. Schalch. 1992. "Development and Implementation of a Multi-Utility Residential New Construction Program: The Energy Crafted Home Program." In Volume 5 - Utility Programs - Proceedings of the ACEEE 1992 Summer Study on Energy Efficiency in Buildings, pp. 63-73. American Council for an Energy-Efficient Economy, Washington, D.C.

Gerhardinger, P. F., and A. M. Flagg. 1992. "Energy Conservation in Existing Buildings Using High Performance Pyrolytic Low-E Glass." In Volume 1 - Commercial Technologies: Design and Operation - Proceedings of the ACEEE 1992 Summer Study on Energy Efficiency in Buildings, pp. 81-87. American Council for an Energy-Efficient Economy, Washington, D.C.

Johnson, A. W. 1987. A Preliminary Analysis of Proposal 87-20 (MIMA) to the Model Energy Code. Johnson and Associates, Gaithersburg, Maryland. 
Lortz, V. B., and Z. T. Taylor. 1989. Recommendations for Energy Conservation Standards for New Residential Buildings. Volume 2: Automated Residential Energy Standard - User's Guide - Version 1.1. PNL-6878 Vol. 2, Pacific Northwest National Laboratory, Richland, Washington.

R. S. Means Company, Inc. (Means). 1994. Means Residential Cost Data-1995. Kingston, Massachusetts.

Money. January 1992. "From Tax Heaven in Alaska to Hell in New York." pp. 74-75.

National Appliance Energy Conservation Act of 1987, Public Law 100-12, 42 USC 6291 et seq., as amended.

National Association of Home Builders (NAHB). 1981. 1980 Base Case and Feasibility Analysis. NAHB Research Center, Upper Marlboro, Maryland.

National Association of Home Builders (NAHB). 1991a. Builder Magazine. March 1991, p. 146.

National Association of Home Builders (NAHB). 1991b. 1991 NAHB Research Foundation Special Report. NAHB Research Center, Upper Marlboro, Maryland.

National Association of Home Builders (NAHB). 1992. Profile of the New Home Buyer. Washington, D.C.

National Association of Home Builders (NAHB). 1995. Housing Market Statistics. Auguist 1995. Washington, D.C.

National Fenestration Rating Council (NFRC). 1994. Certified Products Directory. Second Edition. Silver Spring, Maryland.

Pacific Northwest National Laboratory. 1995. MECcheck ${ }^{\text {nt }}$ Software User's Guide Version 2.0. Pacific Northwest National Laboratory, Richland, Washington.

Strategic Utility Market Services. 1995. New Residential Construction Baseline and Spillover Study. Strategic Utility Market Services, Quakertown, Pennsylvania.

U.S. Department of Commerce (DOC). 1992. Survey of Current Business. Washington, D.C.

U.S. Department of Commerce (DOC). 1995. Survey of Current Business. Washington, D.C. 
U.S. Department of Energy (DOE). 1989a. Technical Support Documentation for the Automated Residential Energy Standards (ARES), In Support of Proposed Interim Energy Conservation Voluntary Performance Standards for New Non-Federal Residential Buildings. DOE/CE-0274, Vol. 4, Washington, D.C.

U.S. Department of Energy (DOE). 1989b. Technical Support Documentation for the Automated Residential Energy Standards (ARES), In Support of. Proposed Interim Energy Conservation Voluntary Performance Standards for New Non-Federal Residential Buildings. DOE/CE-0274, Vol. 2, Washington, D.C.

U.S. Office of Thrift Supervision (OTS). 1991. Rates and Terms on Conventional Home Mortgages. Federal Housing Finance Board, Washington, DC.

Xenergy. 1995. Characterization of Residential New Construction Building Practices in Gas-Heated Homes in Massachusetts. Xenergy, Burlington, Massachusetts.

25 
. 


\section{Appendix A}

\section{Results for Electric Resistance Heating}





\section{Results for Electric Resistance Heating}

The Massachusetts state code has more stringent requirements if electric resistance heating is used instead of any other fuel or heating equipment type. This appendix reports the economic impacts resulting from compliance with the 1995 MEC instead of the current state code when electric resistance heating is used.

Table A.1 shows the energy-efficiency measures meeting the state code: requirements if electric resistance heating is used. The MEC does not have different requirements by fuel or equipment type, so the energy-efficiency measures meeting the MEC do not change from those shown on page 16.

Table A.1. Energy-Efficiency Measures for the Massachusetts State Code, Electric Resistance Heating

\begin{tabular}{|c|c|c|c|c|}
\hline & $\begin{array}{c}\text { Ceiling } \\
\text { Insulation }\end{array}$ & $\begin{array}{c}\text { Wall } \\
\text { Insulation }\end{array}$ & Window Type & $\begin{array}{l}\text { Basement } \\
\text { Insulation }\end{array}$ \\
\hline Single family & R-30 & $\begin{array}{l}\mathrm{R}-13 \text { batt }+ \\
\mathrm{R}-7 \text { sheathing }\end{array}$ & $\begin{array}{l}\mathrm{U}-0.38 \text {, Double } \\
\text { vinyl or wood with } \\
\text { low-E }\end{array}$ & R-11 \\
\hline Multifamily. & $R-49$ & $\begin{array}{l}\text { R-15 batt }+ \\
\text { R-7 sheathing }\end{array}$ & $\begin{array}{l}\mathrm{U}-0.30 \text {, Double } \\
\text { vinyl or wood with } \\
\text { low-E and argon }{ }^{(\mathrm{a})}\end{array}$ & R-11 \\
\hline
\end{tabular}

First Costs

The first cost is the-incremental retail cost to purchase and install energy features in the house including the builder's profit. This is the change in first costs (assuming no mortgage) from the construction changes needed for compliance with the 1995 MEC.

Results for single-family homes are reported first. In Boston, the cost to comply with the state code is actually $\$ 283$ higher than the cost to comply with the MEC. Because the MEC requirements increase in stringency in colder parts of the state, the MEC exceeds the state code electric resistance requirements. Compliance with the MEC is \$273 and \$255 more expensive than compliance with the state code in Worcester and Pittsfield, respectively.

In the MEC, the envelope requirements for walls are less stringent for multifamily units than for single-family houses. For the multifamily. prototype examined here, the Massachusetts code is extremely stringent because of the high window-to-wall area. Compliance with the MEC instead of the state code will significantly decrease construction costs, with 
Mortgages: Down Payment, Monthly Payment, and Tax Deductions first cost decreases of $\$ 1426, \$ 1019$, and $\$ 822$ in Boston, Worcester, and Pittsfield, respectively.

It is assumed here that a single-family home buyer makes a down payment of $20 \%$ of the loan amount and a more financially limited multifamily home buyer makes a down payment of $10 \%$ of the loan amount. Table A.2 shows how mortgage-related costs will be impacted for a 30-year fixed-rate mortgage. The up-front costs include the down payment, points, and loan fees. The savings from income tax deductions of the mortgage interest will slowly decrease over time, and the values shown in Table A.2 are for the first year. Negative numbers indicate MEC compliance will decrease costs because the MEC is less stringent than the state code.

Table A.2. Impacts of Mortgage Costs

\begin{tabular}{||l|c|c|c||}
\hline \multirow{2}{*}{} & \multicolumn{3}{|c|}{ Cost Change Per Housing Unit } \\
\cline { 2 - 4 } & Boston & Worcester & Pittsfield \\
\hline \hline Annual mortgage payment increase \\
$\begin{array}{l}\text { Single family } \\
\text { Multifamily }\end{array}$ & $-\$ 21$ & $\$ 20$ & $\$ 19$ \\
\hline Down payment increase & $-\$ 118$ & $-\$ 84$ & $-\$ 68$ \\
$\quad \begin{array}{l}\text { Single family } \\
\text { Multifamily }\end{array}$ & $-\$ 60$ & $\$ 58:$ & $\$ 54$ \\
\hline First year tax deduction savings & $-\$ 161$ & $-\$ 115$ & $-\$ 93$ \\
$\quad$ Single family & $-\$ 6$ & $\$ 6$ & $\$ 5$ \\
Multifamily & $-\$ 21$ & $-\$ 15$ & $-\$ 12$ \\
\hline
\end{tabular}

Table A.3 shows the estimated energy cost savings resulting from compliance with the MEC instead of the state code. Again, the state code is more stringent for single-family homes in.Boston and multifamily buildings in all locations. Therefore, the energy cost savings from MEC compliance are negative in these cases-energy costs will increase, not decrease.

Table A.3. Annual Energy Cost Savings

\begin{tabular}{||l|c|c|c|}
\hline \multirow{2}{*}{} & \multicolumn{3}{|c|}{ Cost Change Per Housing Unit } \\
\cline { 2 - 4 } & Boston & Worcester & Pittsfield \\
\hline \hline Single family & $-\$ 290$ & $\$ 15$ & $\$ 23$ \\
\hline Multifamily & $-\$ 396$ & $-\$ 211$ & $-\$ 246$ \\
\hline
\end{tabular}


Net Annual Savings
Table A. 4 shows the net annual savings, including energy costs, mortgage payments, property tax, and mortgage tax deduction, but not including the up-front costs. Most of the numbers are negative, indicating the state code requirements will result in lower annual costs than the MEC requirements. The more stringent state requirements are cost-justified because of the high cost of electricity.

Table A.4. Net Annual Cost Savings

\begin{tabular}{||l|c|c|c|}
\hline \multirow{2}{*}{} & \multicolumn{3}{|c|}{ Cost Change Per Housing Unit } \\
\cline { 2 - 4 } & Boston & Worcester & Pittsfield \\
\hline \hline Single family & $-\$ 272$ & $-\$ 2$ & $\$ 7$ \\
\hline Multifamily & $-\$ 283$ & $-\$ 131$ & $-\$ 181$ \\
\hline
\end{tabular}





\section{Appendix B}

Measures of Costs and Benefits Relative to Current Practice 



\section{Measures of Costs and Benefits Relative to Current Practice}

This section presents the findings of the cost/benefit analysis of increasing energy efficiency in Massachusetts dwellings from current practice (when current practice exceeds the state code) to the levels necessary to comply with the 1995 MEC. As will be shown below, the costs and benefits of complying with the MEC relative to current practice are often much less than the costs and benefits relative to the state code minimums shown in the main report.

As shown in Table B.1, the only difference between current practice measures and state code compliance measures is that windows with a $\mathrm{U}$-value of 0.50 are assumed rather than windows with a U-value of 0.72 . A recent study of the current residential window market in Massachusetts reported the average new single-family home had windows with U-values of 0.46 (Pacific Energy Associates, Inc. 1995). The U-0.50 used here represents a basic double wood or vinyl window; some windows installed in new homes also have low-E coatings and/or argon gas which lower the $\mathrm{U}$-value further. Only results for single-family houses and fossil-fuel heating fuels are presented here because these are the only instances when the less-efficient U-0.72 windows were assumed for compliance with the state code in the main report. Table B.2 shows all the energy-efficiency . measures assumed here for current new construction practice.

Table B.1. Difference Between State Code Minimum Requirements and New Home Current Practice for Single-Family, Fossil-Fuel Heated Homes

\begin{tabular}{|l|l|}
\hline & \multicolumn{1}{|c|}{ Window Type } \\
\hline \hline $\begin{array}{l}\text { State Code Minimum } \\
\text { Requirements }\end{array}$ & $\begin{array}{l}\text { U-0.72, Double } \\
\text { aluminum }\end{array}$ \\
\hline $\begin{array}{l}\text { New Construction } \\
\text { Current Practice }\end{array}$ & $\begin{array}{l}\text { U-0.50, Double vinyl } \\
\text { or wood }\end{array}$ \\
\hline
\end{tabular}

Table B.2. Energy-Efficiency Measures for Current Practice in Massachusetts Single-Family, Fossil-Fuel Heated Homes

\begin{tabular}{|c|c|c|c|c||}
\hline & $\begin{array}{c}\text { Ceiling } \\
\text { Insulation }\end{array}$ & \multicolumn{1}{|c|}{$\begin{array}{c}\text { Wall } \\
\text { Insulation }\end{array}$} & Window Type & $\begin{array}{c}\text { Basement } \\
\text { Insulation }\end{array}$ \\
\hline \hline Single family & $\mathrm{R}-30$ & $\mathrm{R}-11$ batt & $\begin{array}{l}\text { U-0.50, Double } \\
\text { vinyl or wood }\end{array}$ & $\mathrm{R}-11$ \\
\hline
\end{tabular}

First Costs

Table B. 3 compares the increase in first costs (assuming no mortgage) from the construction changes needed for compliance with the 1995 MEC instead of current practice. For comparison, the cost increase for the MEC relative 
to the state code minimums are reproduced here (these are the same figures presented in the main report). As can be seen, the first cost increases resulting from MEC compliance are reduced by about two-thirds for Boston and by almost half for the other cities. Again, this reduction in cost increase is because the window energy-efficiency for current practice exceeds the state code requirements.

Table B.3. First Cost Impacts

\begin{tabular}{|l|c|c|c|}
\hline \multirow{2}{*}{} & \multicolumn{3}{|c|}{ Cost Increase Per Housing Unit } \\
\cline { 2 - 4 } & Boston & Worcester & Pittsfield \\
\hline \hline MEC '95 relative to current practice & $\$ 420$ & $\$ 935$ & $\$ 868$ \\
\hline $\begin{array}{l}\text { MEC '95 relative to state code } \\
\text { minimums }\end{array}$ & $\$ 1273$ & $\$ 1738$ &.$\$ 1615$ \\
\hline
\end{tabular}

Mortgages: Down Payment, Monthly Payment, and Tax Deductions
Energy Cost Savings
Table B. 4 shows how mortgage-related costs will be impacted for a 30-year fixed-rate mortgage. The up-front costs include the down payment, points, and loan fees. The savings from income tax deductions of the mortgage interest will slowly decrease over time, and the values shown in Table B.4 are for the first year.

Table B.4. Impacts of Mortgage Costs

\begin{tabular}{|l|c|c|c|}
\hline \multirow{2}{*}{\multicolumn{1}{|c|}{}} & \multicolumn{3}{|c|}{ Cost Increase Per Housing Unit } \\
\cline { 2 - 4 } & Boston & Worcester & - Pittsfield \\
\hline \hline Annual mortgage payment increase & $\$ 31$ & $\$ 69$ & $\$ 64$ \\
\hline Up front cost increase & $\$ 88$ & $\$ 197$ & $\$ 183$ \\
\hline First year tax deduction savings & $\$ 9$ & $\$ 20$ & $\$ 18$ \\
\hline
\end{tabular}

Table B.5 shows the estimated energy cost savings by heating fuel/equipment type resulting from the increased level of energy efficiency required by the MEC. Energy cost savings are higher for natural gas than for oil because natural gas is more expensive. As with first costs, the energy cost impacts from MEC compliance are much lower when compared to current practice (shown here) instead of the state code minimums (shown on page 5). 
Table B.5. Annual Energy Cost Savings

\begin{tabular}{|l|c|c|c|}
\hline \hline \multicolumn{4}{|c|}{ Cost Change Per Housing Unit } \\
\hline $\begin{array}{c}\text { Heating } \\
\text { Fuel Type }\end{array}$ & Boston & Worcester & Pittsfield \\
\hline \hline Natural gas & $\$ 102$ & $\$ 196$ & $\$ 249$ \\
Oil & $\$ 77$ & $\$ 139$ & $\$ 161$ \\
\hline \hline
\end{tabular}

Net Annual Savings

Table B.6 shows the net annual savings, including energy costs, mortgage payments, property tax, and mortgage tax deduction, but not including the up-front costs.

Table B.6. Net Annual Cost Savings

\begin{tabular}{|c|c|c|c|}
\hline \hline \multicolumn{4}{|c|}{ Cost Change Per Housing Unit } \\
\hline $\begin{array}{c}\text { Heating } \\
\text { Fuel Type }\end{array}$ & Boston & Worcester & Pittsfield \\
\hline \hline Natural gas & $\$ 76$ & $\$ 138$ & $\$ 195$ \\
Oil & $\$ 51$ & $\$ 81$ & $\$ 108$ \\
\hline \hline
\end{tabular}

Time to Recovery of Investment

Table B.7 shows the number of years until the homeowner realizes a net cost savings from the increased levels of energy efficiency (i.e., the cumulative savings exceeds the cumulative expenditures). This length of time was derived from the calculation of the up-front costs, mortgage payments, energy costs, property tax, and mortgage interest tax deductions. Note that the return of investment shown here for the MEC relative to current practice is as quick or quicker than the return of investment for the MEC relative to the state code minimums, which are shown in Table 4 on page 7.

Table B.7. Years to Recovery of Investment

\begin{tabular}{|l|c|c|c|}
\hline $\begin{array}{c}\text { Heating } \\
\text { Fuel Type }\end{array}$ & Boston & Worcester & Pittsfield \\
\hline \hline Natural gas & 2 & 2 & 1 \\
Oil & 2 & 3 & 2 \\
\hline
\end{tabular}

\section{Life-Cycle Costs}

The life-cycle cost is the present value of all costs and benefits, with future costs and/or benefits discounted to account for the lower value of money in the future relative to the present. With a 30-year period of analysis and a $4.0 \%$ real discount rate, the present value of life-cycle cost savings from compliance with the $1995 \mathrm{MEC}$ for the single-family house varies from 
$\$ 534$ for an oil-heated house in Boston to $\$ 2101$ for a gas-heated house in Pittsfield.

\section{References}

Pacific Energy Associates, Inc. 1995. Windows of Opportunity:

Residential Window Efficiency and Opportunities for Market Transformation in Massachusetts. Pacific Energy Associates, Inc., Portland, Oregon. 


\section{Appendix C}

Sensitivity of Results to Other Input Parameter Values 



\section{Sensitivity of Results to Other Input Parameter Values}

In the analysis presented in the main body of this report, numerous assumptions were made. If different assumptions were made, the costs and benefits of the MEC would change. This appendix examines the impacts of changing a number of key assumptions. For this sensitivity analysis, all results are relative to the $2240 \mathrm{ft}^{2}$ two-story house in Boston with gas heating. The parameters below are examined one at a time with all other assumptions identical to those presented in the main body of this report. As in the main report, the results shown are the incremental impacts of complying with the 1995 MEC instead of the state code. The parameters examined in this appendix are:

- The use of basement ceiling insulation instead of basement wall insulation.

- The use of a lower window area-10\% of the wall area instead of $14 \%$ of the wall area.

- No central air conditioning.

- Different single-family house designs.

\section{Basement Insulation}

Window Area
An option for insulating unconditioned basements is to insulate the basement ceiling instead of the basement walls. Insulating the basement ceilings is likely to be less expensive than insulating the basement walls. However, insulating the basement walls has the advantage of keeping the basement warmer. If the homeowner has any plans to use the basement as practical living space (such as a family room), the basement-wall insulation will reduce energy costs and improve comfort. Also, if the basement walls are . insulated, ducts located in the basement do not have to be insulated.

Insulating basement ceilings instead of basement walls will have no impact in terms of changing from the state code to the MEC because the MEC and the state code have essentially the same requirements. Both codes effectively require $\mathrm{R}-11$ for basement walls or $\mathrm{R}-19$ for basement ceilings.

A window area of $14 \%$ of the gross exterior wall area was assumed for the single-family house in this report. Window areas in actual houses will vary from a minimum of about $5 \%$ of the wall area to perhaps $20 \%$ or more of the wall area. The MEC has the same gross wall (i.e., wall, window, and doors combined) heat loss requirements regardless of window area.

Because windows are less energy efficient than insulated walls, the use of less windows reduces gross wall heat loss and, therefore, gains credit in meeting the MEC gross wall requirements. The MEC effectively allows some lowering of other measures because of this credit. The energyefficiency measures required for compliance with the MEC for the house with a $10 \%$ window area are identical to those for the house with a $14 \%$ 
window area (see Table 6 on page 16) except that the windows no longer need to be low-E.

For the Massachusetts state code, if the combined window and door area does not exceed $15 \%$ of the gross wall area, the code has requirements that do not change with window area. For the decrease in window area considered here (14\% to $10 \%)$, the state code requirements do not change.

Table C.1 shows the economic impacts of complying with the MEC instead . of the state code for the house with the $14 \%$ window area and the house with the $10 \%$ window area. The $14 \%$ window area column has the same . results presented in the main report. 'In the $10 \%$ window area column, a house with $10 \%$ window area is assumed for both the state code and the MEC. For the house with the $10 \%$ window area, the first cost increase goes down by approximately $40 \%$ because there are less windows and because low-E glass is not needed for MEC compliance. The energy cost savings from compliance with the MEC decrease by $46 \%$ if the house has the lower window area.

Table C.1. Economic Impacts of Smaller Window Area

\begin{tabular}{||l|c|c||}
\hline \multirow{2}{*}{} & \multicolumn{2}{|c|}{$\begin{array}{c}\text { Cost Impacts of the MEC Per } \\
\text { Housing Unit, Boston }\end{array}$} \\
\cline { 2 - 3 } & $\begin{array}{c}14 \% \text { window } \\
\text { area }\end{array}$ & $\begin{array}{c}10 \% \text { window } \\
\text { area }\end{array}$ \\
\hline \hline First cost increase & $\$ 1273$ & $\$ 756$ \\
\hline Annual mortgage payment increase & $\$ 94$ & $\$ 56$ \\
\hline Down payment increase & $\$ 268$ & $\$ 159$ \\
\hline First year tax deduction savings & $\$ 27$ & $\$ 16$ \\
\hline Annual energy cost savings & $\$ 243$ & $\$ 131$ \\
\hline Net annual cost savings & $\$ 164$ & $\$ 84$ \\
\hline Years to recovery of investment & 2 & 2 \\
\hline
\end{tabular}

Air Conditioning
Some but not all new dwellings built in Massachusetts are being equipped - with central air conditioning. In the analysis conducted for this report, dwellings in Boston were assumed to have air conditioning, while dwellings in Worcester and Pittsfield were not. The cost of the air conditioner itself should be the same regardless of the energy efficiency code so the only impacts of interest here are energy cost impacts. Table C. 2 shows the change in energy cost savings for the Boston, gas-heated, two-story house. The annual air conditioning energy costs savings from the more stringent MEC envelope requirements are only $\$ 15$; while the natural gas heating cost savings are $\$ 228$. Therefore, the presence or lack of central air conditioning has little effect on the change in energy costs resulting from the change in energy-efficiency codes. 
Table C.2. Economic Impacts of No Air Conditioning

\begin{tabular}{||l|c|c|}
\hline \multirow{2}{*}{} & \multicolumn{2}{|c|}{$\begin{array}{c}\text { Cost Impacts of the MEC Per } \\
\text { Housing Unit, Boston }\end{array}$} \\
\cline { 2 - 3 } & $\begin{array}{c}\text { With Air } \\
\text { Conditioning }\end{array}$ & $\begin{array}{c}\text { Without Air } \\
\text { Conditioning }\end{array}$ \\
\hline Annual energy cost savings & $\$ 243$ & $\$ 228$ \\
\hline Net annual cost savings & $\$ 164$ & $\$ 149$ \\
\hline Years to recovery of investment & 2 & 2 \\
\hline
\end{tabular}

\section{House Prototype}


Table C.3. Economic Impacts of Different House Design

\begin{tabular}{||l|c|c|c||}
\hline \multirow{2}{*}{} & \multicolumn{3}{|c|}{$\begin{array}{r}\text { Cost Impacts of the MEC Per } \\
\text { Housing Unit, Boston }\end{array}$} \\
\cline { 2 - 4 } & $\begin{array}{c}2240 \mathrm{ft}^{2} \\
\text { two-story }\end{array}$ & $\begin{array}{c}1248 \mathrm{ft}^{2} \\
\text { ranch }\end{array}$ & $\begin{array}{c}768 \mathrm{ft}^{2} \\
\text { cape }\end{array}$ \\
\hline \hline First cost increase & $\$ 1273$ & $\$ 693$ & $\$ 522$ \\
\hline Annual mortgage payment increase & $\$ 94$ & $\$ 51$ & $\$ 38$ \\
\hline Down payment increase & $\$ 268$ & $\$ 146$ & $\$ 110$ \\
\hline First year tax deduction savings & $\$ 27$ & $\$ 15$ & $\$ 11$ \\
\hline Annual energy cost savings & $\$ 243$ & $\$ 129$ & $\$ 97$ \\
\hline Net annual cost savings & $\$ 164$ & $\$ 86$ & $\$ 65$ \\
\hline Years to recovery of investment & 2 & 2 & 2 \\
\hline
\end{tabular}




\section{Distribution}

No. of

Copies

OFFSITE

3 U.S. Department of Energy

Office of Codes and Standards

1000 Independence Ave. SW

Washington, DC 20585

Attn:J. J. Boulin, EE-43

S. J. Turchen, EE-43

R. B. Majette, EE-43
No. of

Copies

80 Pacific Northwest Laboratory

L. M. Connell

K5-16

C. C. Conner

K5-16

D. R. Conover

R. G. Lucas (65)

BWO

T. L. Odell, Program Files (5)

Information Release Office (7)
$\mathrm{K} 5-16$

K5-02

K1-11

\section{ONSITE}

DOE Richland Operations Office

J. K. Schmitz

K8-50 


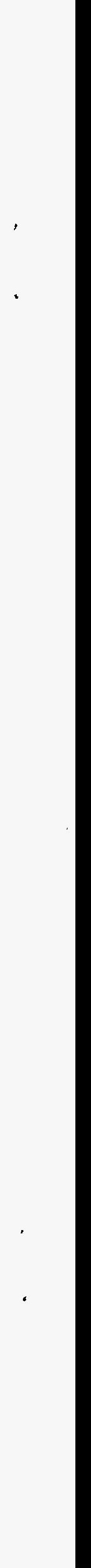

